\title{
Characterization of Novel Torrefied Biomass and Biochar Amendments
}

\author{
Heather D. Baldi ${ }^{1}$, Tyler L. Foster ${ }^{1}$, Xiaoqing Shen ${ }^{1}$, Sam E. Feagley ${ }^{1}$, \\ Fred E. Smeins ${ }^{2}$, Dirk B. Hays ${ }^{1}$, Russell W. Jessup ${ }^{{ }^{*}}$ \\ ${ }^{1}$ Department of Soil \& Crop Sciences, Texas A\&M University, College Station, TX, USA \\ ${ }^{2}$ Department of Ecosystem Science and Management, Texas A\&M University, College Station, TX, USA \\ Email: hdbaldi@tamu.edu, „rjessup@tamu.edu
}

How to cite this paper: Baldi, H.D., Foster, T.L., Shen, X., Feagley, S.E., Smeins, F.E., Hays, D.B. and Jessup, R.W. (2020) Characterization of Novel Torrefied Biomass and Biochar Amendments. Agricultural Sciences, 11, 157-177.

https://doi.org/10.4236/as.2020.112010

Received: January 18, 2020

Accepted: February 14, 2020

Published: February 17, 2020

Copyright $\odot 2020$ by author(s) and Scientific Research Publishing Inc. This work is licensed under the Creative Commons Attribution International License (CC BY 4.0).

http://creativecommons.org/licenses/by/4.0/

\begin{abstract}
Nutrient management is vital for food, feed, fiber, and fuel production. However, excessive application and loss (volatilization, leaching, run-off, etc.) of inorganic and organic sources of nutrients have detrimental environmental impacts, while increasing prices for petroleum-based and mined fertilizers further limit opportunities for their utilization in developing nations. This study evaluated a novel, alternative type of nutrient source through pretreatment processes of torrefaction and pyrolysis by converting high-biomass feedstocks into renewable soil amendments. Napiergrass (Pennisetum purpureum Schumach., [cv. Merkeron]) and pearl millet-napiergrass (Pennisetum glaucum [L.] R. Br. $\times$ P. purpureum Schumach.) $(\mathrm{PMN})$ were converted under atmospheric pressure with minimal oxygen at $250^{\circ} \mathrm{C}$ and $400^{\circ} \mathrm{C}$, ground to 1 millimeter $(\mathrm{mm})$ and $2 \mathrm{~mm}$ particle sizes, and compared to urea in a full-season field trial and short-season nursery trial growing maize (Zea mays L.) and PMN for fertility response. When compared to urea in the field trial, the torrefied biomass amendment (TBA) and biochar had similar responses despite lower nitrogen $(\mathrm{N})$ application rates. The nursery trial also produced equivalent responses from urea and TBA regardless of lower $\mathrm{N}$ application with the exception being phosphorus (P). Finally, maize and PMN had higher $\mathrm{P}$ uptake with the TBA in both trials.
\end{abstract}

\section{Keywords}

Torrefaction, Biochar, Pyrolysis, Soil Amendment, Organic Nutrient Source

\section{Introduction}

Fertilizer use has increased dramatically to meet increasing global population 
demands for food and fiber [1], and there is a projected $100 \%-110 \%$ increase in global crop demands between the years 2005 to 2050 [2]. Inorganic fertilizer makes up the bulk of nutrient inputs needed to sustain current crop yields [3]. Adequate fertilization of crops increases nutritional quality [4], while excessive application and loss of inorganic and organic sources of nutrients have significant, harmful environmental impacts [5] [6]. Excessive nitrogen (N) can increase yield; however, it can also reduce both nutritional quality (vitamin $\mathrm{C}$ ), soluble sugars, magnesium $(\mathrm{Mg})$ and calcium $(\mathrm{Ca})[4]$ as well as other plant nutrients. Increased prices for petroleum-based and mined fertilizers further limit opportunities for their utilization in developing countries [7] [8]. Production of $\mathrm{N}$ fertilizer has increased since 1962, yet its distribution is not globally uniform [9]. Organic farming can help offset inorganic fertilizer costs in developing countries; however, [10] approximately 50\% of all applied $\mathrm{N}$ is lost through leaching, erosion, and denitrification [11]. Incorporation of manure and crop residue can produce a higher percentage of water stable aggregates, lower bulk density, higher porosity, and greater water holding capacity [12] [13] [14] as slow-release fertilizers [15]. Composted cattle manure further provides higher $\mathrm{P}$, $\mathrm{K}$, and Ca concentrations without affecting grain yield [16]. There is, however, risk of increased environmental impacts that processing manures into mineral fertilizers has on terrestrial acidification and particulate matter formation [17]. The application of compost or manure is also typically not economically viable with agronomic $\mathrm{N}$ rates in modern, high-input, mechanized cropping systems [18]. In addition, manures may contain contaminants, including residual pesticides, hormones, pathogens, and weed seed [19] [20]. Prolonged manure use can lead to excessive amounts of phosphorus (P) [21] [22].

To offset the increase of inorganic fertilizer use or problematic organic inputs, alternative forms of renewable nutrient amendments need to be developed. One alternative is the use of an organic nutrient amendment that can be created from thermally modified, high-biomass feedstocks. These pretreatment processes include pyrolysis and torrefaction, and they break down plant structures while retaining nutrients. The end product is fertile and carbon (C) rich with added soil health benefits from sequestering $\mathrm{C}$, improving cation exchange capacity, increasing water retention, reduced leaching, and enhancing nutrient cycling [23] [24]. The $\mathrm{C}$ mineralization rate of this product can last from hundreds to in excess of 1000 years depending on the thermal conversion conditions [23] [25] [26]. Pyrolysis and torrefaction derived products offer renewable, pathogen free, and weed seed free soil amendments. The charcoal particles in the soil prevent nutrients from leaching and therefore have higher concentrations of $\mathrm{N}, \mathrm{P}$, potassium (K), and Ca. Biochar conversion strategies can take diverse sources of agricultural waste and produce effective soil enhancers [27] [28]. Additionally, biochar in soils can have in situ remediation benefits that include: stabilization of contaminants like copper $(\mathrm{Cu})$ and lead $(\mathrm{Pb})$, the ability to act as a liming agent, and C sequestration [29] [30] [31] [32] [33]. In clay-enriched, compacted 
soils, biochar can also have a reduction in tensile strength while potentially increasing field capacity [27].

Biochar is however not widely used due to its high cost, which ranges from US $\$ 197$ - 584 per ton [34]. In contrast, the average US farm price of urea was US $\$ 434$ per ton in June of 2019 [35]. Biochar further has lower N content and high compositional variability dependent upon the conditions of pyrolysis and feedstock utilized [36] [37]. Biochar effects may also prove to be soil specific [38]. To date, biochar utilization has been predominately focused in biocoal, syngas, bio-oil, and hydrothermal production of biomass under anaerobic conditions. Ultimately, biochar application to soils is dependent upon parent material, temperature rates, and application rates [36] [37] [38] [39].

Torrefaction is a milder form of pyrolysis, requiring less energy than biochar [40]. When biomass is torrefied-devolatilization, depolymerization, and carbonization of hemicellulose, lignin, and cellulose occur to varied degrees [41]. Lignin that is not devolatilized is loosened, hemicellulose is broken down, and the resulting intermediate between biomass and charcoal retains nutrients [42]. Torrefaction ranges are often reported from $200^{\circ} \mathrm{C}-300^{\circ} \mathrm{C}$ in an inert environment at atmospheric pressure, whereas biochar is typically carried out at temperatures significantly higher than $300^{\circ} \mathrm{C}$ [40] [42] [43] [44]. Pyrolysis temperatures above $300^{\circ} \mathrm{C}$ decrease the cellulose and hemicellulose contents [36], and pyrolysis temperatures higher than $500^{\circ} \mathrm{C}$ decrease cation exchange capacity while increasing macronutrient concentrations [25]. Post-torrefaction $\mathrm{N}$ concentration in torrefied biomass amendment (TBA) can be inversely proportional to its feedstock composition. This can be attributed to $\mathrm{N}$ volatilization in feedstocks like poultry litter and $\mathrm{N}$ being stored organically like in uric acid. However, lower $\mathrm{N}$ concentrations in feedstocks like pine chips can be retained in complex structures that do not easily volatilize [45]. Field applications for TBA can come from high biomass feedstocks such as pearl millet-napiergrass (PMN), napiergrass, or legumes. This can result in soil amendments from a single feedstock with no pathogens and up to $4 \%-5 \% \mathrm{~N}$. When compared to raw biomass, the $\mathrm{C}$ content of torrefied biomass increases by $15 \%-25 \%$ and the moisture content decreases to less than 3\% [41]. Torrefaction decreases the energy conversion by about $70 \%$ compared to pyrolysis, improves grindability via fracturing cell walls, and increases both particle surface area and size distribution. Finally, torrefaction can improve moisture, $\mathrm{C}$, hydrogen $(\mathrm{H})$, and calorific value [41] [46] [47]. Like biochar, torrefied biomass has been predominantly utilized in the coal and energy industry [48] [49]. The recalcitrant torrefied C fraction provides benefits similar to biochar, including enhancing water retention, soil structural stability, soil metabolites, and plant growth promoting microbiota [50].

To determine if torrefied and pyrolyzed biomass amendments can be used as a nutrient source in cropping systems, the first objective of this study was to develop and characterize novel torrefied and pyrolyzed (biochar) biomass amend- 
ments. The second objective was to compare biomass yield responses and nutrient status from TBA, biochar, and urea in perennial PMN and annual maize in two environments. These environments included a full-growing season field trial and a partial-growing season nursery trial.

\section{Materials and Methods}

\subsection{Biomass Pretreatment}

The PMN and napiergrass (Merkeron) feedstocks utilized in the development of the TBA and biochar were harvested in November 2016 and May 2017, respectively. PMN biomass was converted into TBA and biochar that was utilized in the field trial, whereas the Merkeron biomass was converted into TBA that was utilized in the nursery trial. Each feedstock's biomass was air-dried under greenhouse conditions for a week, and then placed in a drying oven at $43^{\circ} \mathrm{C}$ for 24 hours. The biomass for both feedstocks was separately ground to a maximum particle size of 5.1 centimeters $(\mathrm{cm})$ using a Cub Cadet chipper shredder model \#24A-424M756. The homogeneous bulked sample of ground material, weighing 2.72 kilograms $(\mathrm{kg})$, was placed into a $35 \mathrm{~cm} \times 25.4 \mathrm{~cm}$ fixed bed stainless steel reactor and compressed to a bulk density of 200 kilograms per meter cubed $\left(\mathrm{kg} / \mathrm{m}^{3}\right)$ for each feedstock. The reactor was then placed under an Axner Model Heat Wave Raku Kiln model \#A255655 (Terrakotta, Inc., Oviedo, FL) and sealed with low oxygen. A propane torch was connected to a propane tank to provide the constant heat needed to achieve the $250^{\circ} \mathrm{C}$ for torrefaction. A Type $\mathrm{K}$ Thermocouple was placed inside the stainless steel reactor to monitor the temperature's rate of increase. A Bartlett Data Logger Pyrometer (Bartlett Instrument Company Fort Madison, IA) was used to monitor the temperature rise which was maintained at less than two degrees per minute. Once the target temperature of $250^{\circ} \mathrm{C}$ was reached, the reactor was held at a constant for a 45 minute incubation period. Once the incubation period was completed, the propane tank valve was closed to let the reactor cool. The biomass was then emptied from the reactor after cooling for a minimum of 12 hours. The treated biomass was then weighed on a digital scale for mass loss during torrefaction. Samples of the treated material were ground to 2 millimeter $(\mathrm{mm})$ and $1 \mathrm{~mm}$ particle sizes using a Wiley Mill standard model No. 3 serial \#3720H-5 (Thomas Scientific Swedesboro, $\mathrm{NJ})$.

The overall methodology for the biochar was the same as that for the TBAs except for the target temperature. The temperature rise was maintained at less than four degrees per minute. Once the target temperature of $400^{\circ} \mathrm{C}$ was achieved, the reactor was held at that constant temperature for a 60 minute incubation period. The final treated biomass was then weighed for mass loss during pyrolysis, and ground to $2 \mathrm{~mm}$ and $1 \mathrm{~mm}$ particle sizes.

\subsection{Field Trial}

The full growing season field trial was conducted at the Texas A\&M Agricultural 
Research Farm in Burleson County in Snook, TX (30 32'48.2"N 96 26 $\left.06.1^{\prime \prime} \mathrm{W}\right)$. There were three replications; two crop varieties: PMN10TX13 and VT Triple Pro Hybrid Corn: D57VP5; two soil amendments-TBA and biochar-and a control fertilizer: urea (46-0-0); and two amendment particle sizes: $2 \mathrm{~mm}$ and 1 $\mathrm{mm}$. Individual plots were $0.5 \mathrm{~m} \times 4.5 \mathrm{~m}$, with each plot being spaced $0.5 \mathrm{~m}$ within rows, and alley spacing in between plots measuring $2.5 \mathrm{~m}$. The crops chosen for this research were based on forage use and seasonality. Maize was chosen for its widespread use as a food and forage annual crop. PMN was chosen for its adaptability as a 'seeded-yet-sterile' perennial biomass crop [51].

The soil series, where the field trial was conducted, is a combination of Ships and Weswood. Ships is a very fine, mixed, active, thermic Chromic Hapluderts and Weswood is a fine-silty, mixed, superactive, thermic Udifluventic Haplustepts. The Ships series is a clayey soil with alluvial sediments whereas Weswood series is a stratified, loamy soil with alluvial sediments [52]. Typical soil property values for this soil series include $\mathrm{pH} 7.8$ - 8 and conductivity 220 - 250 micromhos per centimeter (umho/cm) (unpublished data). In order to determine residual nutrient content in the soil before planting, a representative soil sample of the field was taken. An Oakfield Company soil probe was used to take 10 random soil cores at a depth of $15 \mathrm{~cm}$. The 10 soils cores were then put into a clean bucket and mixed together by hand to create a representative soil sample.

Planting for the full growing season field trial took place on May 8, 2017 after the field had been disked. Planting followed a randomized complete block design (RCBD). The two varieties were planted differently due to their growth patterns. The maize was planted by seed with spacing of $2.5 \mathrm{~cm}$ between seed and a depth of $2.5 \mathrm{~cm}$ using a Jang Automation JP-1 Clean Seeder. The PMN was planted vegetatively. PMN plants had been growing from germinated seed in propagation trays for approximately a month before being planted. The PMN was spaced $30.5 \mathrm{~cm}$ apart in the $0.5 \mathrm{~m} \times 4.5 \mathrm{~m}$ plot for a total of 13 plants per row.

Application rates for the TBA and biochar were 23 kilograms N/hectare (kg $\mathrm{N} / \mathrm{ha}$ ), $10 \mathrm{~kg} \mathrm{P} / \mathrm{ha}$, and $60 \mathrm{~kg} \mathrm{~K} / \mathrm{ha}$. The application rate for urea was $166 \mathrm{~kg}$ $\mathrm{N} / \mathrm{ha}$. The amendments and fertilizer were side dressed into the plots. TBA, biochar, and urea were applied at different rates due to a comparison of slow-release and fast-release sources of nutrients. Overall, urea had approximately seven times more elemental $\mathrm{N}$ than the TBA and biochar per plot.

The field was flood irrigated to field capacity at planting and two more times-July 12, 2017 and August 6, 2017-to ensure adequate growth.

The field harvest for maize took place 106 days after planting (DAP) to ensure physiological maturity. The field harvest for PMN took place 205 DAP and prior to the season's first frost. All plots were clipped to a $10 \mathrm{~cm}$ height and weighed wet using an Inscale DSWR load cell weigh rail. A subsample was taken from the total harvest of each plot. This subsample was then weighed wet and allowed to air-dry for three days before being put into a drying oven, at $43^{\circ} \mathrm{C}$, for 24 hours to remove residual moisture. The subsamples were then weighed dry to calculate 
total moisture content before being ground to $1 \mathrm{~mm}$ particle size using a Wiley Mill. After grinding, 10 grams (g) of each subsample were used to determine total plant analyses including nutrient and forage content.

\subsection{Nursery Trial}

A partial growing season nursery trial was conducted at the Perennial Grass Breeding and Genetics Field Lab in Brazos County in College Station, TX. There were four replications; two crop varieties: PMN10TX13 and VT Triple Pro Hybrid Corn: D57VP5; one soil amendment-TBA and a control fertilizer: urea (46-0-0); and one amendment particle size: $2 \mathrm{~mm}$. Each variety was planted in an 11 liter (L) $-25.4 \mathrm{~cm}$ high and $0.28 \mathrm{~m}$ diameter-pot for a total of 16 pots. Each pot was filled with Sunshine Redi-Earth Plug \& Seedling Mix (Sun Gro Horticulture Agawam, MA) as artificial growing media with fine sphagnum, peat moss, vermiculite, and dolomite lime. The artificial growing media also contained a wetting agent and had low drainage with a fine particle size.

Planting of the nursery trial was completed on July 19, 2017. Planting followed an RCBD. The two varieties were planted by seed. The pots designated maize had two seeds placed in the middle of each pot at a depth of $2.5 \mathrm{~cm}$ to ensure germination. The pots designated PMN had three seeds placed in the middle of each pot in a hill seed approach at a depth of $1.3 \mathrm{~cm}$ to ensure germination. To avoid competition within the pot, each pot was thinned to one seedling post emergence. The spacing between each pot measured $10.2 \mathrm{~cm} \times 12.7 \mathrm{~cm}$ with 61 $\mathrm{cm}$ between each replication. The pots were irrigated to field capacity each time as needed in order to prevent drought stress, and observed daily to ensure proper growth.

The application rate for the TBA was $26.5 \mathrm{~kg} \mathrm{~N} / \mathrm{ha}, 10 \mathrm{~kg}$ P/ha, and $128 \mathrm{~kg}$ $\mathrm{K} / \mathrm{ha}$. The application rate for urea was $166 \mathrm{~kg} \mathrm{~N} / \mathrm{ha}$. Overall, urea had six times more elemental nitrogen than the TBA per pot. To approximate side dressing in the field, the amendment and fertilizer were applied in a circular furrowed perimeter around the seed with a diameter of $10.2 \mathrm{~cm}$ and a depth of $1.3 \mathrm{~cm}$.

Harvesting took place 72 DAP on September 29, 2017. All pots were clipped at the crown of the plant. Each plant was weighed wet on a digital scale and allowed to air-dry for three days before being put into a drying oven, at $43^{\circ} \mathrm{C}$, for 24 hours to remove residual moisture. The samples were weighed dry to calculate total moisture content before being ground to $1 \mathrm{~mm}$ particle size using a Wiley Mill. After grinding, $10 \mathrm{~g}$ of each sample were used to determine total plant analyses as specified for the field test.

\subsection{Soil and Plant Analyses and Statistics}

All nutrient, forage, and soil testing for this study was completed by the Texas A \& M AgriLife Extension Service Soil, Water and Forage Testing Laboratory in College Station, TX. The field trial analyzed Acid Detergent Fiber (ADF), Total Digestive Nutrients (TDN), yield measured in tonnes per hectare (T/ha), percent 
macronutrient- $\mathrm{N}, \mathrm{P}, \mathrm{K}, \mathrm{Ca}, \mathrm{Mg}-$ content, and nutrient- $\mathrm{N}, \mathrm{P}, \mathrm{K}-$ uptake in biomass per plot. The nutrient uptake in biomass per plot was calculated by taking the percent nutrient and dividing it by the dry matter yield as described in University of Arkansas Agriculture Research and Extension publication [53]. The nursery trial analyzed ADF, TDN, yield measured in g, and percent nutrient $-\mathrm{N}, \mathrm{P}, \mathrm{K}-$ content. Data collected from the field and nursery trials was first tested for normal distribution and homogeneity of variance. Data was then submitted to analysis of variance (ANOVA) testing, an assumption check using Levene's test for equality of variances, and a post-hoc comparison using Tukey's honest significant difference test (HSD) mean \pm standard error (SE). Differences were considered significant at $p \leq 0.05,0.01$, and 0.001 . All statistical analyses were completed with JMP Pro v. 14.0.0 (SAS Institute, 2019).

\section{Results}

\subsection{Pretreatment Processes}

Since there was experimental variation in the feedstocks utilized in the development of TBA and biochar, forage quality analyses focusing on percent elemental $\mathrm{N}, \mathrm{P}$, and $\mathrm{K}$ were conducted on the PMN and Merkeron feedstocks before pretreatment and after the $250^{\circ} \mathrm{C}$ torrefaction and $400^{\circ} \mathrm{C}$ pyrolysis pretreatment process (Table 1) for characterization of the substrate. As stated earlier, the PMN and Merkeron feedstocks utilized were homogeneous bulked samples. The percentage of $\mathrm{N}$ retained in the feedstock increased minimally per each pretreatment process. Untreated PMN was $0.74 \% \mathrm{~N}$, whereas the TBA was $0.75 \%$, and the biochar was $0.80 \%$. Similarly, the percent of $\mathrm{P}$ retained in the feedstock increased with each pretreatment process. Untreated PMN started at $0.24 \% \mathrm{P}$, while the TBA retained $0.34 \%$, and biochar measured $0.57 \%$. Lastly, $\mathrm{K}$ had higher retention increases with each pretreatment process than $\mathrm{N}$ or $\mathrm{P}$. Untreated PMN was measured at $1.52 \% \mathrm{~K}$. The PMN TBA increased retention and was recorded at $1.97 \% \mathrm{~K}$, while biochar almost doubled the amount of $\mathrm{K}$ available at $2.98 \%$.

Unlike the PMN feedstock, the Merkeron feedstock did not increase retention across all macronutrients. $\mathrm{N}$ was slightly reduced after torrefaction, starting at

Table 1. Percent (\%) forage nutrient analyses (elemental N, P, K) in pearl millet-napiergrass (Pennisetum glaucum [L.] R. Br. ×Pennisetum purpureum Schumach.) (PMN) and napiergrass ( $P$. purpureum Schumach., [cv. Merkeron]) feedstocks for untreated and pretreatment processes: torrefaction $\left(250^{\circ} \mathrm{C}\right)$ and pyrolysis $\left(400^{\circ} \mathrm{C}\right)$.

\begin{tabular}{ccccccc}
\hline & \multicolumn{3}{c}{ PMN } & \multicolumn{3}{c}{ Merkeron } \\
\cline { 2 - 7 } & $\mathbf{N}$ & $\mathbf{P}$ & $\mathbf{K}$ & $\mathbf{N}$ & $\mathbf{P}$ & $\mathrm{K}$ \\
\hline Untreated & 0.74 & 0.24 & 1.52 & 1.07 & 0.3 & 3.69 \\
$250^{\circ} \mathrm{C}$ & 0.75 & 0.34 & 1.97 & 0.94 & 0.35 & 4.54 \\
$400^{\circ} \mathrm{C}$ & 0.8 & 0.57 & 2.98 & & & \\
\hline
\end{tabular}


$1.07 \%$ untreated and ending up at $0.94 \% \mathrm{~N}$ after torrefaction. Phosphorus increased slightly from $0.30 \%$ untreated to $0.35 \%$ torrefied. Similar to PMN feedstock pretreatments, the Merkeron pretreatments had the highest increase in $\mathrm{K}$ retention. The untreated Merkeron measured 3.69\% while the TBA measured $4.54 \% \mathrm{~K}$.

\subsection{Field Trial}

The soil for the field trial was tested for residual macronutrient content. The field location had extremely low residual $\mathrm{N}$ measuring at $3 \mathrm{mg} / \mathrm{kg}$ and $\mathrm{P}$ at 21 $\mathrm{mg} / \mathrm{kg}$. The $\mathrm{K}$ at $2520 \mathrm{mg} / \mathrm{kg}$, Ca at $5595 \mathrm{mg} / \mathrm{kg}$, and $\mathrm{Mg}$ at $237 \mathrm{mg} / \mathrm{kg}$ were sufficient for crop production.

The crop differences were not noted in the analyses for this paper due to the differences that were expected when comparing a forage crop and a grain crop. Statistical analyses were conducted on the crops individually; however, due to differing relative maturity times of the crops used, there were significant differences seen between the crops with regard to yield, ADF, TDN, and nutrient content (data not shown). The maize utilized had a relative maturity of 117 growing days versus the PMN that was harvested at 205 DAP and had not entered the reproductive stage. Therefore, the crop and amendment particle size entries as variables were removed and not highlighted in this paper. Additionally, PMN has the potential ability for mining $\mathrm{P}$ out of soils due to its fibrous root system; it was the only crop to have an entry by amendment interaction with the TBA small particle size. Therefore, a one-way ANOVA utilized merged data to compare the nutrient amendments.

Individual amendment effects from the ANOVA are summarized in Table 2,

Table 2. Analysis of variance (ANOVA) summary table of 11 variables for field trial of torrefied, biochar, and urea nutrient amendments in full-season maize and pearl millet-napiergrass $(\mathrm{PMN})$. Significant at $\mathrm{p} \leq 0.05\left(^{*}\right)$.

\begin{tabular}{cc}
\hline Test & Amendment p-value \\
\hline ADF & 0.6190 \\
TDN & 0.6190 \\
Yield (T/ha) & 0.0541 \\
N & 0.5482 \\
P & 0.8650 \\
K & 0.6919 \\
Ca & $0.0317^{*}$ \\
Mg & 0.6627 \\
N uptake & 0.1541 \\
P uptake & 0.0585 \\
K uptake & 0.1704 \\
\hline
\end{tabular}


with significant effects noted at $\mathrm{p} \leq 0.05$. All TBA and biochar amendments performed equivalent to urea, with marginally significant exceptions being yield and significant differences in Ca. Their significant differences each had a p-value of 0.0541 and 0.0317 respectively.

$\mathrm{ADF}$ and TDN are important forage analyses used in relating to the digestibility of the forage to an animal. ADF relates to the cell wall portions of the forage that are cellulose and lignin. TDN is based on ADF and refers to the digestible energy of the forage. It is the sum of the digestible fiber, protein, lipid, and carbohydrate components [54]. ADF and TDN (Figure 1) did not produce significant differences with regard to amendment used. All TBA and biochar amendments performed as well as urea.

Overall yield (T/ha) trended higher with urea but did not reach the threshold for significance (Table 2). Urea appeared to outperform the pyrolized and torrefied amendments shown in Figure 2. Furthermore, there was no difference between the particle sizes of $1 \mathrm{~mm}$ and $2 \mathrm{~mm}$ in the TBA and biochar amendments.

$\mathrm{N}$ is one of the most important nutrients needed for crop production, especially in maize. Total $\mathrm{N}$ content was measured post-harvest, and the levels were not significant (Figure 3). Additionally, $\mathrm{P}$ and $\mathrm{K}$ (Figure 3) yielded no significance in any amendment. This further illustrates that the TBA and biochar were providing equivalent $\mathrm{N}$ as synthetic urea.

$\mathrm{Ca}$ is a vital macronutrient as it directly correlated to cell wall growth [55]. Ca was measured post-harvest (Figure 3 ) and the ANOVA results provide a significant difference with regard to amendment (Table 2). The TBA small particle size had a significant mean whereas the TBA large particle size, biochar, and urea were all similar means.

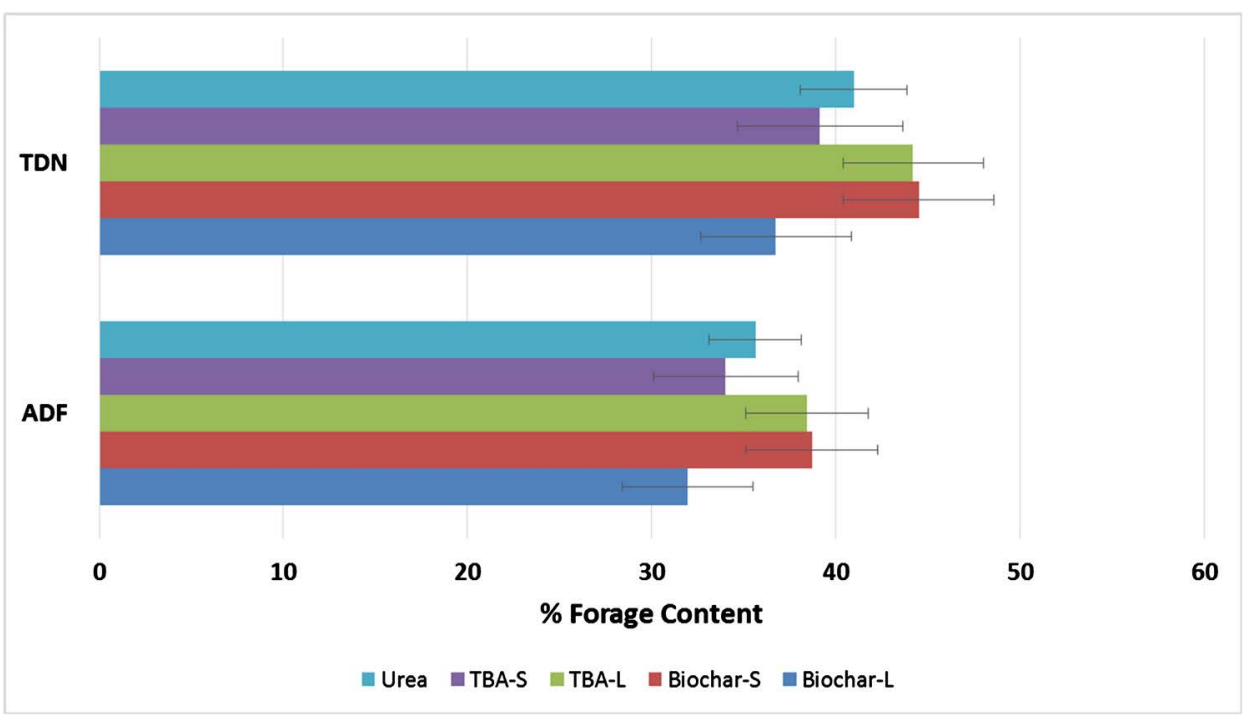

Figure 1. Percent (\%) forage content by amendment: torrefied biomass amendment (TBA), biochar, and urea with amendment sizes of $2 \mathrm{~mm}$ large (L) and $1 \mathrm{~mm}$ small (S) in full-season maize and pearl millet-napiergrass (PMN) field trial. Data expressed as Tukey's HSD mean $( \pm \mathrm{SE})$. Significant at $\mathrm{p} \leq 0.05\left(^{*}\right)$. 


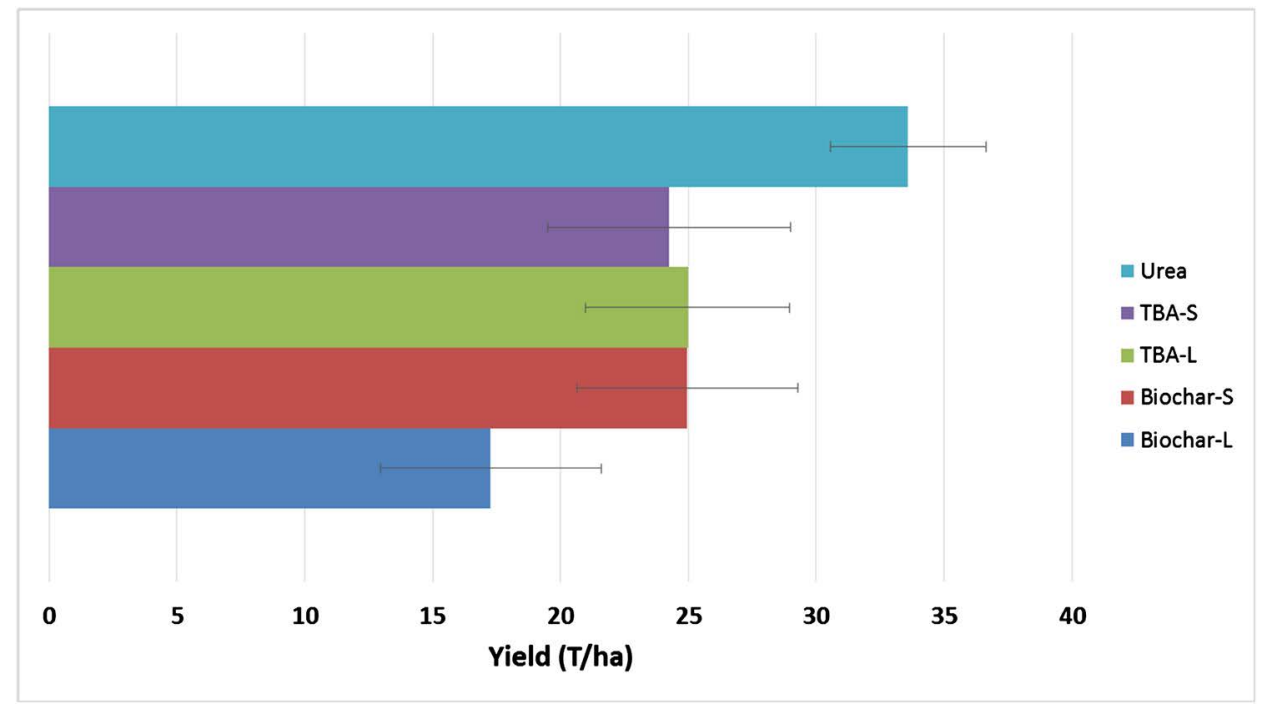

Figure 2. Dry matter yield (T/ha) by amendment: torrefied biomass amendment (TBA), biochar, and urea with amendment sizes of $2 \mathrm{~mm}$ large (L) and $1 \mathrm{~mm}$ small (S) in full-season maize and pearl millet-napiergrass (PMN) field trial. Data expressed as Tukey's HSD mean $( \pm S E)$. Significant at $\mathrm{p} \leq 0.05\left(^{*}\right)$.

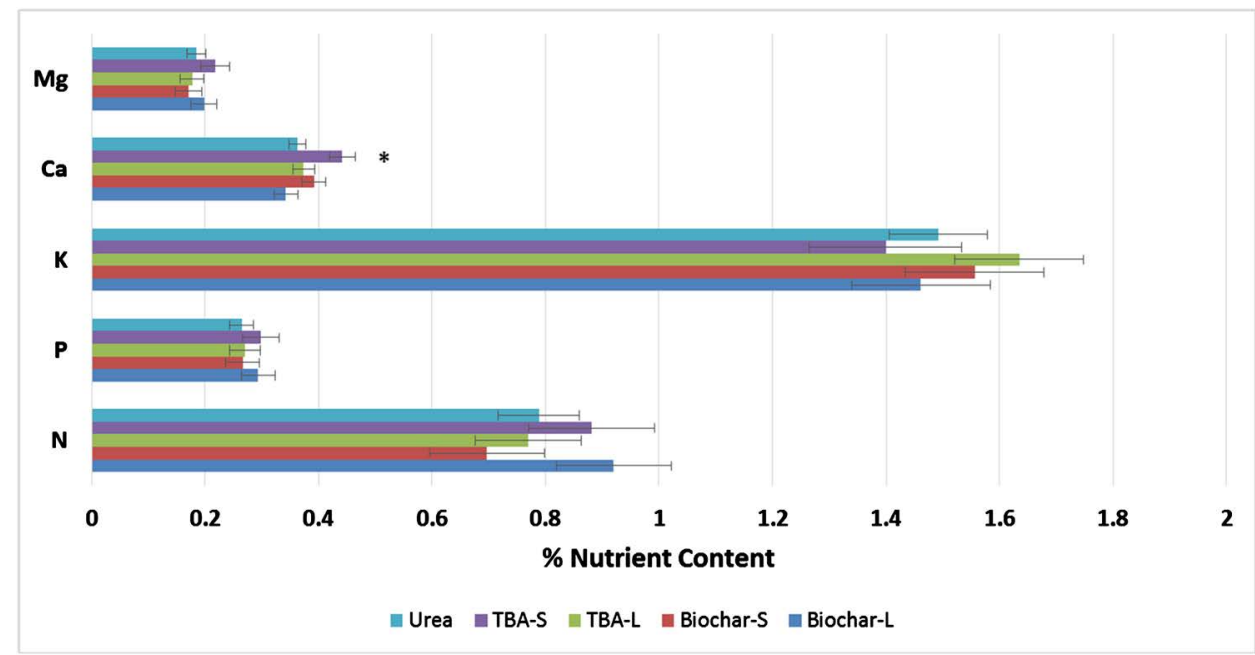

Figure 3. Percent (\%) nutrient content by amendment: torrefied biomass amendment (TBA), biochar, and urea with amendment sizes of $2 \mathrm{~mm}$ large (L) and $1 \mathrm{~mm}$ small (S) in full-season maize and pearl millet-napiergrass (PMN) field trial. Data expressed as Tukey's HSD mean $( \pm \mathrm{SE})$. Significant at $\mathrm{p} \leq 0.05\left(^{*}\right)$.

$\mathrm{Mg}$ is required in lower quantities than $\mathrm{Ca} . \mathrm{Mg}$ is also a key nutrient in the role of photosynthesis. Figure 3 provides the mean results which were nonsignificant. All amendments were providing equivalent $\mathrm{Mg}$.

The overall nutrient uptake in harvested biomass per plot was also analyzed in the full-season field trial. The biomass yield per plot of nutrient uptake was measured for N, P, and K (Figure 4) with no significant differences. Similar to nutrient content in the biomass, total nutrient uptake was equivalent in both crops irrespective of nutrient amendment. 


\subsection{Nursery Trial}

As the nursery trial was to be simplified and optimized for resource allocation as well as a partial-growing season (72 days), the amendment comparison only focused on TBA and urea. The urea fertilizer rate would remain the same as the field trial at $166 \mathrm{~kg} / \mathrm{ha}$ while the TBA would increase slightly at $26.5 \mathrm{~kg} / \mathrm{ha}$. Following the same methodology and reasoning as the field trial, the urea would follow the Texas standard of $134 \mathrm{~kg} \mathrm{~N} / \mathrm{ha}$. The TBA would be applied at a minimum in order to evaluate a yield response.

Individual amendment variable effects from the ANOVA are summarized in Table 3. Significant differences were noted for $\mathrm{P}$ only. TBA provided the most available $\mathrm{K}$ to the plants. As torrefaction has the same beneficial properties as

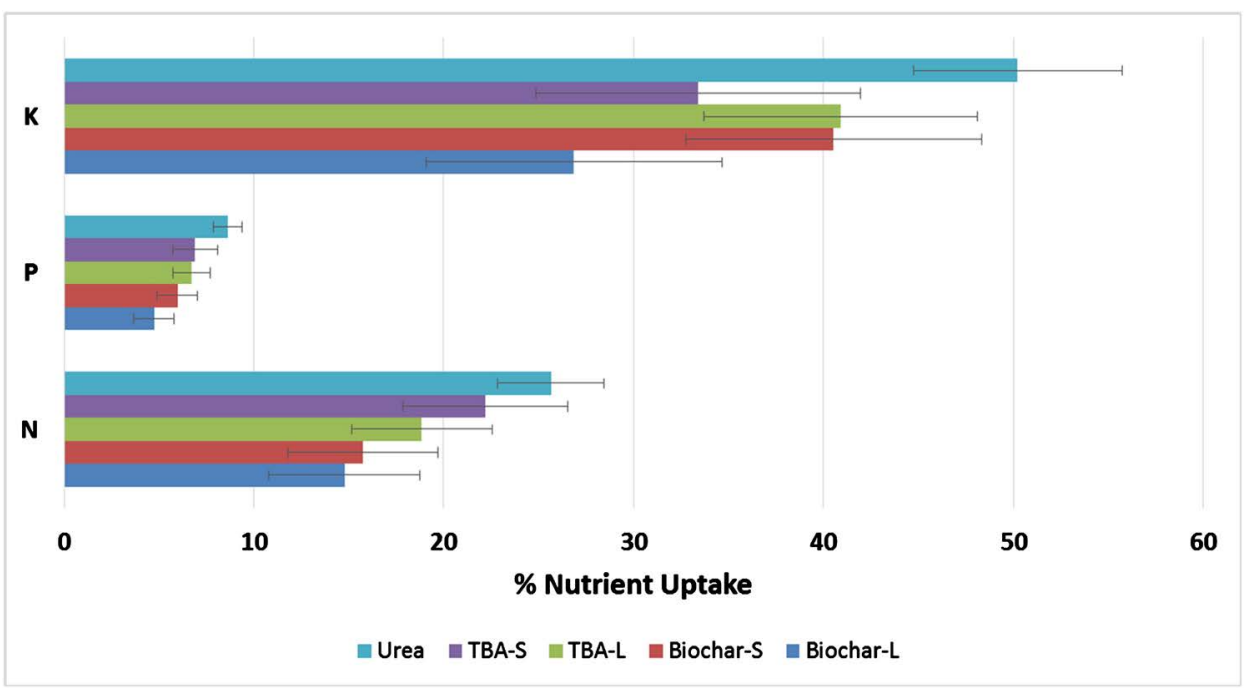

Figure 4. Percent (\%) nutrient uptake by amendment: torrefied biomass amendment (TBA), biochar, and urea with amendment sizes of $2 \mathrm{~mm}$ large (L) and $1 \mathrm{~mm}$ small (S) in full-season maize and pearl millet-napiergrass (PMN) field trial. Data expressed as Tukey's HSD mean $( \pm \mathrm{SE})$. Significant at $\mathrm{p} \leq 0.05\left(^{*}\right)$.

Table 3. Analysis of variance (ANOVA) summary table of eight variables for nursery trial of torrefied and urea nutrient amendments in partial-season maize and pearl millet-napiergrass (PMN). Significant at $\mathrm{p} \leq 0.05\left(^{*}\right)$.

\begin{tabular}{cc}
\hline Test & Amendment p-value \\
\hline ADF & 0.6376 \\
TDN & 0.6376 \\
Yield $(g)$ & 0.3391 \\
N & 0.0752 \\
P & $0.0286^{*}$ \\
K & 0.9566 \\
Ca & 0.7792 \\
Mg & 0.9447
\end{tabular}


biochar, it too would help plants have better P uptake. All other variables produced non-significant results.

As with the full-season field trial, forage analyses were conducted to determine if TBA would provide any hindrance to making the crop less digestible to animals. Figure 5 shows there was no significant difference between TBA and urea with regard to ADF and TDN.

Yield (g) for the nursery trial was not significant in either amendment (Figure 6).

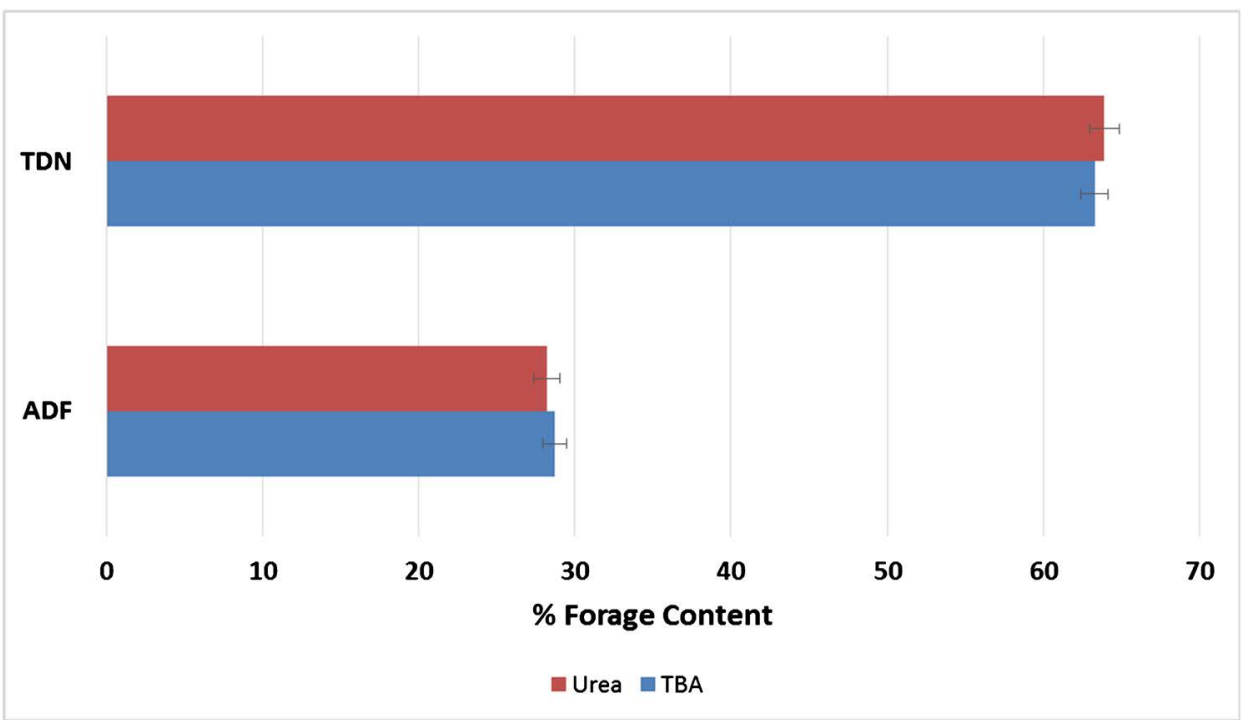

Figure 5. Percent (\%) forage content by amendment: torrefied biomass amendment (TBA) and urea in partial-season maize and pearl millet-napiergrass (PMN) nursery trial. Data expressed as Tukey's HSD mean $\left( \pm\right.$ SE). Significant at $\mathrm{p} \leq 0.05\left(^{*}\right)$.

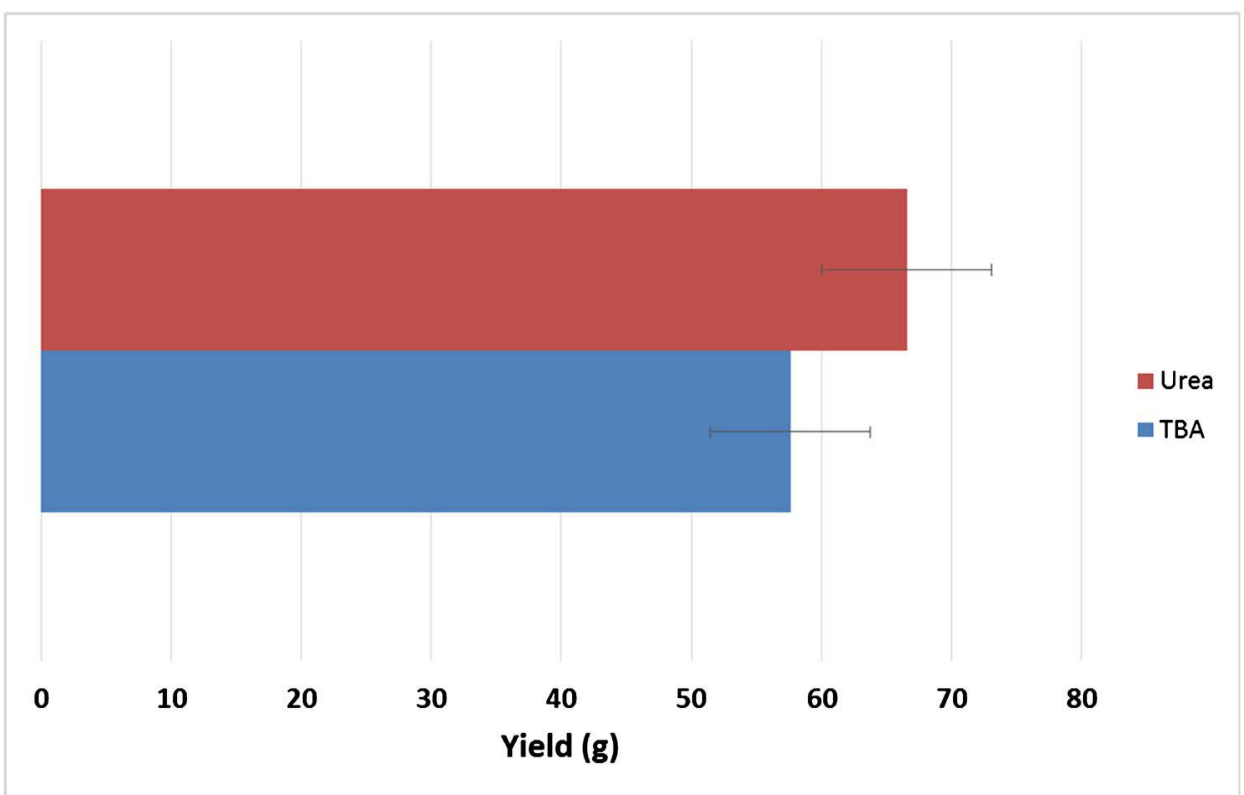

Figure 6. Dry matter yield (g) by amendment: torrefied biomass amendment (TBA) and urea in partial-season maize and pearl millet-napiergrass (PMN) nursery trial. Data expressed as Tukey’s HSD mean $( \pm \mathrm{SE})$. Significant at $\mathrm{p} \leq 0.05\left(^{\star}\right)$. 
Maize would have a higher yield due to its relative maturity, but with respect to the amendment used, neither urea nor TBA was statistically significant.

$\mathrm{N}$ was analyzed post-harvest and the ANOVA test found no significant difference between urea and TBA (Table 3). Similar to N, K was also found to be non-significant statistically (Table 3). This further illustrates that the TBA was providing equivalent $\mathrm{N}$ to the crops as synthetic urea. $\mathrm{P}$ was found to be statistically significant. Figure 7 shows the mean of TBA at 0.191 and a SE of 0.021 and a mean of urea at 0.115 with an SE of 0.23 .

The final two macronutrients to be analyzed were $\mathrm{Ca}$ and $\mathrm{Mg}$ in Figure 7. Similar to $\mathrm{N}$ and $\mathrm{K}, \mathrm{Ca}$ and $\mathrm{Mg}$ yielded non-significant results from ANOVA. These results are on par with results found throughout this study. TBA provided equivalent nutrients as a synthetic fertilizer.

\section{Discussion}

Our results demonstrated that torrefaction and pyrolysis increased nutrient retention among the feedstock selections of PMN and Merkeron. This coincides with previous literature that resulted in an increase in nutrient retention among feedstock selections of woodchips, eucalyptus, and wheat straw [41] [46] [56]. Research conducted on cassava shows that post-pyrolysis the percentage of fixed $\mathrm{C}$ increased 5 - 8 times than when it is raw [57]. C rich materials, like the aforementioned pyrolized cassava, can help prevent leaching and retain nutrients like $\mathrm{Ca}$ [58]. Ca also reduces soil salinity and helps with water retention, therefore an additional benefit of using TBA or biochar would be to offset the effects of an ammonium fertilizer like urea which can lead to volatilization and soil acidification over time [59]. The TBA and biochar developed in this research could be

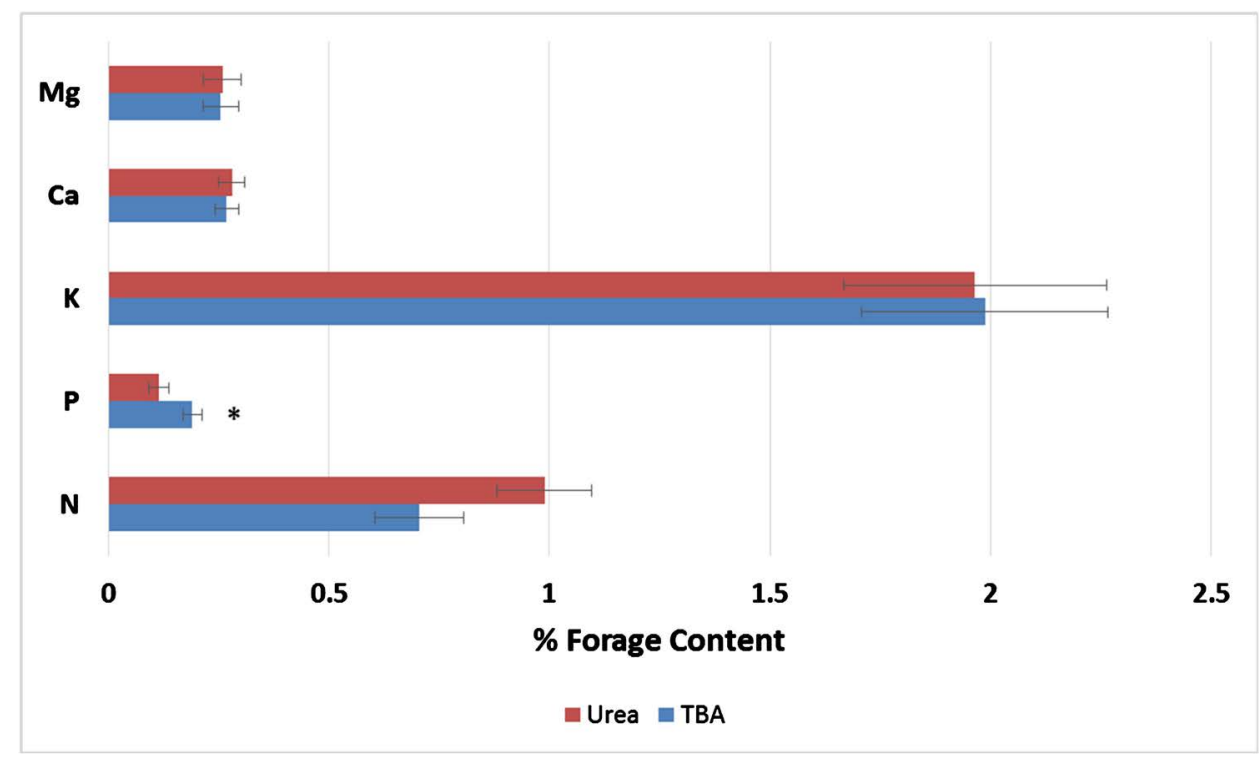

Figure 7. Percent (\%) nutrient content by amendment: torrefied biomass amendment (TBA) and urea in partial-season maize and pearl millet-napiergrass (PMN) nursery trial. Data expressed as Tukey's HSD mean $( \pm \mathrm{SE})$. Significant at $\left.\mathrm{p} \leq 0.05{ }^{(}\right)$. 
used as a nutrient amendment to help with $\mathrm{N}, \mathrm{P}, \mathrm{K}, \mathrm{Ca}$, and $\mathrm{Mg}$ retention [58], which was specifically demonstrated in the nursery trial with regard to $\mathrm{Ca}$ and $\mathrm{P}$. Similar to literature results, $\mathrm{P}$ had more nutrient concentration in the TBA [60]. The use of biochar in another greenhouse study helped to reduce leaching and increased nutrient retention of $\mathrm{N}$ and $\mathrm{P}$ [61], further demonstrating the benefits of torrefied and pyrolized amendments as organic nutrient sources.

The TBA and biochar nutrient amendments both performed as well as urea in the full-season field trial with much lower $\mathrm{N}$ application rates. The demonstration of a fertility response is evidence that nutrients are more plant available post-torrefaction. This coincides with previous literature that had positive fertility responses when adding pyrolized amendments to maize, sugi trees, moong, and soybean [62] [63]. To reiterate, the TBA and biochar in the field trial had seven times less elemental $\mathrm{N}$ than the urea used, and TBA and biochar utilized in the nursery trial had six times less elemental $\mathrm{N}$ than urea. The urea was applied at rates similar to the standard application in Texas for maize production of 134 $\mathrm{kg} / \mathrm{ha}$. The urea application rate of $166 \mathrm{~kg} / \mathrm{ha}$ was slightly higher, but that was to partially offset the potential volatilization and leaching that can occur when using urea [64]. The TBA and biochar application rate of equivalent $\mathrm{N}$ was considerably less than that of the standard rate, at $23 \mathrm{~kg} / \mathrm{ha}$ and $26.5 \mathrm{~kg} / \mathrm{ha}$. The comparatively lower rates were chosen based on the crude protein of the feedstock selections and that the nutrient amendments would be slow-release. The application rate was set at a minimum to evaluate potential yield response. This is further illustrated by the yield results in the field trial where the TBA and biochar were being cycled directly back into the soil considering it is a slow-release nutrient source [65].

Excessively high biochar application rates have previously been demonstrated to cause negative growth responses. As one example, pine and poplar biochar was found to impart a reduction in biomass with application rates of 5 - $19 \mathrm{~T} / \mathrm{ha}$ [66]. The TBA and biochar application rates in this study (approximately 2.5 3.3 T/ha) were intentionally kept below this range in order to avoid such a risk. Further, the comparatively lower TBA and biochar-based $\mathrm{N}$ application rates versus the recommended standard of $134 \mathrm{~kg} \mathrm{~N} /$ ha for inorganic fertilizers helped to minimize cost associated with high biochar inputs. Current prices for biochar remain approximately $\$ 325$ - 500 per ton [67], and applications at even the modest rates in this study would range from $\$ 800-1600$ per ha. Compared to current urea prices of $\$ 434$ per ton [33], its standard fertilization rate would cost only $\$ 60$ per ha. Dramatic reductions in biochar production costs would thus be required before its utilization as a nutrient source. TBAs, in contrast, range from $\$ 120$ - 199 per ton [68]. While lower than biochar costs, TBAs at the application rate in this study would still cost between $\$ 300$ - 650 per ha. Further advancements in TBAs would similarly be required before their consideration as a nutrient source in regions where inorganic fertilizers are available and lower in cost. In developing countries where inorganic fertilizers are cost prohibitive, 
however, on-site production of TBAs could provide a value proposition as alternative nutrient sources for farmers. Considering the potential yield (50 dry T/ha) of napiergrass [69] and the $\mathrm{N}$ content (approximately 1\%) in this study, TBAs with an equivalent of $500 \mathrm{~kg} \mathrm{~N}$ could be produced per ha of biomass feedstock. Depending on recommended fertilization rates, this could be sufficient to supply the $\mathrm{N}$ requirements of $3-10$ ha of major food crops. Average sorghum fertilization rates in Africa, for example, are only $12 \mathrm{~kg} / \mathrm{ha}$ [70] despite World Bank recommendations of at least $50 \mathrm{~kg} / \mathrm{ha}$. Additional cost savings that have yet to be quantified in detail from utilizing torrefied and pyrolized biomass amendments could also include: 1) decreased irrigation costs due to improved soil aggregate structure and increased water retention, 2) increased nutrient use efficiency and deceased $\mathrm{N}$ leaching due to increased cation-exchange capacity and soil microbial activity, and 3) decreased soil liming requirements due to moderation of soil acidity [36] [71] [72] [73]. Coupling these benefits with crop-specific responses ranging from increased seed germination through higher biomass yields [62] strongly indicate the value in expanded research efforts on TBAs as alternative fertilizer sources in the future.

\section{Conclusion}

This research demonstrated a fertility response upon application of TBAs and biochar when compared to an inorganic fertilizer with a minimal application rate. However, further research should be conducted to include multiple feedstock selections to determine optimal nutrient content for use in TBA and biochar amendments, as there is a high compositional variability dependent upon the conditions of pyrolysis and feedstock utilized. Torrefaction can break down the polymers in the plant, which is beneficial. However, high temperature torrefaction can also result in a loss of aromatic hydrocarbon [74]. Therefore, different temperatures should be taken into consideration as torrefaction can occur at multiple temperature settings within $200^{\circ} \mathrm{C}-300^{\circ} \mathrm{C}$. Testing TBA and biochar amendments across more diverse crops and soil types would further optimize cropping systems incorporating these amendments. Different temperatures, feedstocks, incubation times, and application rates would also have further impacts on cropping systems. It is important that TBA and biochar be used in full-season plantings, as the partial-growing season nursery trial showed that crop response would only be beneficial with regard to $\mathrm{P}$ retention. While the energy inputs and costs associated with torrefaction and biochar weren't researched in this study, there is an associated environmental benefit that TBA and biochar can provide with regard to soil health and microbiota.

\section{Acknowledgements}

The authors would like to thank the Department of Energy (DOE) ARPAe grant call number DE-FOA-001261 for funding this research. 


\section{Conflicts of Interest}

The authors declare no conflicts of interest regarding the publication of this paper.

\section{References}

[1] Gunjal, K.R., Roberts, R.K. and Heady, E.O. (1980) Fertilizer Demand Functions for Five Crops in the United States. Journal of Agricultural and Applied Economics, 12, 111-116. https://doi.org/10.1017/S0081305200015703

[2] Tilman, D., Balzer, C., Hill, J. and Befort, B.L. (2011) Global Food Demand and the Sustainable Intensification of Agriculture. Proceedings of the National Academy of Sciences, 108, 20260-20264. https://doi.org/10.1073/pnas.1116437108

[3] Stewart, W., Dibb, D., Johnston, A. and Smyth, T. (2005) The Contribution of Commercial Fertilizer Nutrients to Food Production. Agronomy Journal, 97, 1-6. https://doi.org/10.2134/agronj2005.0001

[4] Wang, Z.H., Li, S.X. and Malhi, S. (2008) Effects of Fertilization and Other Agronomic Measures on Nutritional Quality of Crops. Journal of the Science of Food and Agriculture, 88, 7-23. https://doi.org/10.1002/jsfa.3084

[5] Gilliam, J., Logan, T.J. and Broadbent, F. (1985) Fertilizer Use in Relation to the Environment. In: Fertilizer Technology and Use, Soil Science Society of America, Madison, 561-588.

[6] Keeney, D. and Follett, R. (1991) Managing Nitrogen for Groundwater Quality and Farm Profitability: Overview and Introduction. In: Managing Nitrogen for Groundwater Quality and Farm Profitability, Soil Science Society of America, Madison, 1-7. https://doi.org/10.2136/1991.managingnitrogen.c1

[7] Brunelle, T., Dumas, P., Souty, F., Dorin, B. and Nadaud, F. (2015) Evaluating the Impact of Rising Fertilizer Prices on Crop Yields. Agricultural Economics, 46, 653-666. https://doi.org/10.1111/agec.12161

[8] Huang, W.-Y., McBride, W.D. and Vasavada, U. (2009) Recent Volatility in US Fertilizer Prices: Causes and Consequences. Amber Waves. The Economics of Food, Farming, Natural Resources, and Rural America, 7, 28-31.

[9] Mosier, A.R., Syers, J.K. and Freney, J.R. (2004) Nitrogen Fertilizer: An Essential Component of Increased Food, Feed, and Fiber Production. In: Mosier, A.R., Syers, J.K. and Freney, J.R., Eds., Agriculture and the Nitrogen Cycle: Assessing the Impacts of Fertilizer Use on Food Production and the Environment, Scope Series Vol. 65, Island Press, Washington DC, 3-15.

[10] Scialabba, N. (2000) Factors Influencing Organic Agriculture Policies with a Focus on Developing Countries. IFOAM 2000 Scientific Conference, Basel, 28-31.

[11] Tonitto, C., David, M. and Drinkwater, L. (2006) Replacing Bare Fallows with Cover Crops in Fertilizer-Intensive Cropping Systems: A Meta-Analysis of Crop Yield and N Dynamics. Agriculture, Ecosystems \& Environment, 112, 58-72. https://doi.org/10.1016/j.agee.2005.07.003

[12] Bhagat, R. and Verma, T. (1991) Impact of Rice Straw Management on Soil Physical Properties and Wheat Yield. Soil Science, 152, 108-115. https://doi.org/10.1097/00010694-199108000-00007

[13] Clark, M.S., Horwath, W.R., Shennan, C. and Scow, K.M. (1998) Changes in Soil Chemical Properties Resulting from Organic and Low-Input Farming Practices. Agronomy Journal, 90, 662-671. 
https://doi.org/10.2134/agronj1998.00021962009000050016x

[14] Hati, K., Mandal, K., Misra, A., Ghosh, P. and Bandyopadhyay, K. (2006) Effect of Inorganic Fertilizer and Farmyard Manure on Soil Physical Properties, Root Distribution, and Water-Use Efficiency of Soybean in Vertisols of Central India. Bioresource Technology, 97, 2182-2188. https://doi.org/10.1016/j.biortech.2005.09.033

[15] Pampuro, N., Bertora, C., Sacco, D., Dinuccio, E., Grignani, C., Balsari, P., Cavallo, E. and Bernal, M. (2017) Fertilizer Value and Greenhouse Gas Emissions from Solid Fraction Pig Slurry Compost Pellets. The Journal of Agricultural Science, 155, 1646-1658. https://doi.org/10.1017/S002185961700079X

[16] Gil, M., Carballo, M. and Calvo, L. (2008) Fertilization of Maize with Compost from Cattle Manure Supplemented with Additional Mineral Nutrients. Waste Management, 28, 1432-1440. https://doi.org/10.1016/j.wasman.2007.05.009

[17] De Vries, J., Groenestein, C. and De Boer, I. (2012) Environmental Consequences of Processing Manure to Produce Mineral Fertilizer and Bio-Energy. Journal of Environmental Management, 102, 173-183. https://doi.org/10.1016/j.jenvman.2012.02.032

[18] Evanylo, G., Sherony, C., Spargo, J., Starner, D., Brosius, M. and Haering, K. (2008) Soil and Water Environmental Effects of Fertilizer-, Manure-, and Compost-Based Fertility Practices in an Organic Vegetable Cropping System. Agriculture, Ecosystems \& Environment, 127, 50-58. https://doi.org/10.1016/j.agee.2008.02.014

[19] Kuepper, G. (2003) Manures for Organic Crop Production. ATTRA National Sustainable Agriculture Information Service, IP127, 1-12.

[20] Bàrberi, P. (2002) Weed Management in Organic Agriculture: Are We Addressing the Right Issues? Weed Research, 42, 177-193. https://doi.org/10.1046/j.1365-3180.2002.00277.x

[21] Barnett, G. (1994) Phosphorus Forms in Animal Manure. Bioresource Technology, 49, 139-147. https://doi.org/10.1016/0960-8524(94)90077-9

[22] Ju, X.T., Kou, C.L., Christie, P., Dou, Z. and Zhang, F. (2007) Changes in the Soil Environment from Excessive Application of Fertilizers and Manures to Two Contrasting Intensive Cropping Systems on the North China Plain. Environmental Pollution, 145, 497-506. https://doi.org/10.1016/j.envpol.2006.04.017

[23] Laird, D.A. (2008) The Charcoal Vision: A Win-Win-Win Scenario for Simultaneously Producing Bioenergy, Permanently Sequestering Carbon, While Improving Soil and Water Quality. Agronomy Journal, 100, 178-184. https://doi.org/10.2134/agrojnl2007.0161

[24] Malghani, S., Gleixner, G. and Trumbore, S.E. (2013) Chars Produced by Slow Pyrolysis and Hydrothermal Carbonization Vary in Carbon Sequestration Potential and Greenhouse Gases Emissions. Soil Biology and Biochemistry, 62, 137-146. https://doi.org/10.1016/j.soilbio.2013.03.013

[25] Harris, K., Gaskin, J., Cabrera, M., Miller, W. and Das, K. (2013) Characterization and Mineralization Rates of Low Temperature Peanut Hull and Pine Chip Biochars. Agronomy, 3, 294-312. https://doi.org/10.3390/agronomy3020294

[26] Wu, M., Han, X., Zhong, T., Yuan, M. and Wu, W. (2016) Soil Organic Carbon Content Affects the Stability of Biochar in Paddy Soil. Agriculture, Ecosystems \& Environment, 223, 59-66. https://doi.org/10.1016/j.agee.2016.02.033

[27] Chan, K.Y., Van Zwieten, L., Meszaros, I., Downie, A. and Joseph, S. (2007) Agronomic Values of Greenwaste Biochar as a Soil Amendment. Soil Research, 45, 
629-634. https://doi.org/10.1071/SR07109

[28] Windeatt, J.H., Ross, A.B., Williams, P.T., Forster, P.M., Nahil, M.A. and Singh, S. (2014) Characteristics of Biochars from Crop Residues: Potential for Carbon Sequestration and Soil Amendment. Journal of Environmental Management, 146, 189-197. https://doi.org/10.1016/j.jenvman.2014.08.003

[29] Beesley, L., Moreno-Jiménez, E., Gomez-Eyles, J.L., Harris, E., Robinson, B. and Sizmur, T. (2011) A Review of Biochars' Potential Role in the Remediation, Revegetation and Restoration of Contaminated Soils. Environmental Pollution, 159, 3269-3282. https://doi.org/10.1016/j.envpol.2011.07.023

[30] Karami, N., Clemente, R., Moreno-Jiménez, E., Lepp, N.W. and Beesley, L. (2011) Efficiency of Green Waste Compost and Biochar Soil Amendments for Reducing Lead and Copper Mobility and Uptake to Ryegrass. Journal of Hazardous Materials, 191, 41-48. https://doi.org/10.1016/j.jhazmat.2011.04.025

[31] Manyuchi, M., Stinner, W., Mbohwa, C. and Muzenda, E. (2018) Integrated Biomass Utilization for Energy Efficiency and Nutrient Recycling. Proceedings of the International Conference on Industrial Engineering and Operations Management, Washington DC, 27-29 September 2018, 120-128.

[32] Rodríguez-Vila, A., Asensio, V., Forján, R. and Covelo, E.F. (2015) Chemical Fractionation of $\mathrm{Cu}, \mathrm{Ni}, \mathrm{Pb}$ and $\mathrm{Zn}$ in a Mine Soil Amended with Compost and Biochar and Vegetated with Brassica juncea L. Journal of Geochemical Exploration, 158, 74-81. https://doi.org/10.1016/j.gexplo.2015.07.005

[33] Woolf, D., Amonette, J.E., Street-Perrott, F.A., Lehmann, J. and Joseph, S. (2010) Sustainable Biochar to Mitigate Global Climate Change. Nature Communications, 1, Article No. 56. https://doi.org/10.1038/ncomms1053

[34] Shackley, S., Hammond, J., Gaunt, J. and Ibarrola, R. (2011) The Feasibility and Costs of Biochar Deployment in the UK. Carbon Management, 2, 335-356. https://doi.org/10.4155/cmt.11.22

[35] Quinn, R. (2019) DTN Retail Fertilizer Trends, Retail Urea Prices Continue to Trend Higher.

https://www.dtnpf.com/agriculture/web/ag/crops/article/2019/06/12/retail-urea-pri ces-continue-trend

[36] Kavitha, B., Reddy, P.V.L., Kim, B., Lee, S.S., Pandey, S.K. and Kim, K.-H. (2018) Benefits and Limitations of Biochar Amendment in Agricultural Soils: A Review. Journal of Environmental Management, 227, 146-154. https://doi.org/10.1016/j.jenvman.2018.08.082

[37] Spokas, K.A. (2010) Review of the Stability of Biochar in Soils: Predictability of O:C Molar Ratios. Carbon Management, 1, 289-303. https://doi.org/10.4155/cmt.10.32

[38] Zhu, Q., Peng, X. and Huang, T. (2015) Contrasted Effects of Biochar on Maize Growth and N Use Efficiency Depending on Soil Conditions. International Agrophysics, 29, 257-266. https://doi.org/10.1515/intag-2015-0023

[39] Gonzaga, M.I.S., Mackowiak, C., de Almeida, A.Q., de Carvalho Junior, J.I.T. and Andrade, K.R. (2018) Positive and Negative Effects of Biochar from Coconut Husks, Orange Bagasse and Pine Wood Chips on Maize (Zea mays L.) Growth and Nutrition. Catena, 162, 414-420. https://doi.org/10.1016/j.catena.2017.10.018

[40] Nhuchhen, D.R., Basu, P. and Acharya, B. (2014) A Comprehensive Review on Biomass Torrefaction. International Journal of Renewable Energy \& Biofuels, 2014, 1-56. https://doi.org/10.5171/2014.506376

[41] Tumuluru, J.S., Wright, C.T., Hess, J.R. and Kenney, K.L. (2011) A Review of Bio- 
mass Densification Systems to Develop Uniform Feedstock Commodities for Bioenergy Application. Biofuels, Bioproducts and Biorefining, 5, 683-707. https://doi.org/10.1002/bbb.324

[42] Mitchell, D. and Elder, T. (2010) In Torrefaction? What's That? Proceedings of 2010 COFE: 33rd Annual Meeting of the Council on Forest Engineering, Auburn, 6-9 June 2010, 1-7.

[43] Chen, W.H. and Kuo, P.C. (2011) Torrefaction and Co-Torrefaction Characterization of Hemicellulose, Cellulose and Lignin as Well as Torrefaction of Some Basic Constituents in Biomass. Energy, 36, 803-811. https://doi.org/10.1016/j.energy.2010.12.036

[44] Novak, J.M., Lima, I., Xing, B., Gaskin, J.W., Steiner, C., Das, K., Ahmedna, M., Rehrah, D., Watts, D.W. and Busscher, W.J. (2009) Characterization of Designer Biochar Produced at Different Temperatures and Their Effects on a Loamy Sand. Annals of Environmental Science, 3, 195-206.

[45] Gaskin, J.W., Steiner, C., Harris, K., Das, K. and Bibens, B. (2008) Effect of Low-Temperature Pyrolysis Conditions on Biochar for Agricultural Use. Transactions of the ASABE, 51, 2061-2069. https://doi.org/10.13031/2013.25409

[46] Nunes, L.J.R., Matias, J.C.O. and Catalão, J.P.S. (2014) A Review on Torrefied Biomass Pellets as a Sustainable Alternative to Coal in Power Generation. Renewable and Sustainable Energy Reviews, 40, 153-160.

https://doi.org/10.1016/j.rser.2014.07.181

[47] Pimchuai, A., Dutta, A. and Basu, P. (2010) Torrefaction of Agriculture Residue to Enhance Combustible Properties. Energy \& Fuels, 24, 4638-4645. https://doi.org/10.1021/ef901168f

[48] Chen, W.H., Peng, J.H. and Bi, X.T.T. (2015) A State-of-the-Art Review of Biomass Torrefaction, Densification and Applications. Renewable \& Sustainable Energy Reviews, 44, 847-866. https://doi.org/10.1016/j.rser.2014.12.039

[49] Junsatien, W., Soponpongpipat, N. and Phetsong, S. (2013) Torrefaction Reactors. Journal of Science and Technology Mahasarakham University, 32, 84-91.

[50] Ogura, T., Date, Y., Masukujane, M., Coetzee, T., Akashi, K. and Kikuchi, J. (2016) Improvement of Physical, Chemical, and Biological Properties of Aridisol from Botswana by the Incorporation of Torrefied Biomass. Scientific Reports, 6, Article No. 28011. https://doi.org/10.1038/srep28011

[51] Jessup, R.W. (2013) Seeded-Yet-Sterile' Perennial Biofuel Feedstocks. Advances in Crop Science and Technology, 1, e102.

[52] Soil Survey Staff, Natural Resources Conservation Service, United States Department of Agriculture. Official Soil Series Descriptions.

https://www.nrcs.usda.gov/wps/portal/nrcs/detail/soils/survey/geo/?cid=nrcs142p2 053587

[53] Roberts, T., Kirkpatrick, W., Slaton, N. and Norman, R. (2012) Estimating Nutrient Removal for Row Crops Grown in Arkansas. Extension Publications (UofA).

[54] Belyea, R.L., Steevens, B.J., Garner, G.B., Whittier, J.C. and Sewell, H.B. (1993) Using NDF and ADF to Balance Diets. Extension Publications (MU).

[55] Rorison, I. and Robinson, D. (1984) Calcium as an Environmental Variable. Plant, Cell \& Environment, 7, 381-390. https://doi.org/10.1111/j.1365-3040.1984.tb01427.x

[56] Rousset, P., Macedo, L., Commandré, J.M. and Moreira, A. (2012) Biomass Torrefaction under Different Oxygen Concentrations and Its Effect on the Composition of the Solid By-Product. Journal of Analytical and Applied Pyrolysis, 96, 86-91. 
https://doi.org/10.1016/j.jaap.2012.03.009

[57] Noor, N.M., Shariff, A. and Abdullah, N. (2012) Slow Pyrolysis of Cassava Wastes for Biochar Production and Characterization. Iranian (Iranica) Journal of Energy \& Environment, 3, 60-65.

[58] Glaser, B., Haumaier, L., Guggenberger, G. and Zech, W. (2014) The "Terra Preta" Phenomenon: A Model for Sustainable Agriculture in the Humid Tropics. Naturwissenschaften, 88, 37-41. https://doi.org/10.1007/s001140000193

[59] Tong, D. and Xu, R. (2012) Effects of Urea and $\left(\mathrm{NH}_{4}\right)_{2} \mathrm{SO}_{4}$ on Nitrification and Acidification of Ultisols from Southern China. Journal of Environmental Sciences, 24, 682-689. https://doi.org/10.1016/S1001-0742(11)60832-2

[60] Ok, Y.S., Uchimiya, S.M., Chang, S.X. and Bolan, N. (2015) Biochar: Production, Characterization, and Applications. CRC Press, Boca Raton. https://doi.org/10.1201/b18920

[61] Altland, J.E. and Locke, J.C. (2012) Biochar Affects Macronutrient Leaching from a Soilless Substrate. HortScience, 47, 1136-1140. https://doi.org/10.21273/HORTSCI.47.8.1136

[62] Glaser, B., Lehmann, J. and Zech, W. (2002) Ameliorating Physical and Chemical Properties of Highly Weathered Soils in the Tropics with Charcoal: A Review. Biology and Fertility of Soils, 35, 219-230. https://doi.org/10.1007/s00374-002-0466-4

[63] Iswaran, V., Jauhri, K.S. and Sen, A. (1980) Effect of Charcoal, Coal and Peat on the Yield of Moong, Soybean and Pea. Soil Biology \& Biochemistry, 12, 191-192. https://doi.org/10.1016/0038-0717(80)90057-7

[64] Aarnio, T. and Martikainen, P.J. (1994) Mineralization of Carbon and Nitrogen in Acid Forest Soil Treated with Fast and Slow-Release Nutrients. Plant and Soil, 164, 187-193. https://doi.org/10.1007/BF00010070

[65] Yao, Y., Gao, B., Chen, J. and Yang, L. (2013) Engineered Biochar Reclaiming Phosphate from Aqueous Solutions: Mechanisms and Potential Application as a Slow-Release Fertilizer. Environmental Science \& Technology, 47, 8700-8708. https://doi.org/10.1021/es4012977

[66] Marks, E.A., Alcañiz, J.M. and Domene, X. (2014) Unintended Effects of Biochars on Short-Term Plant Growth in a Calcareous Soil. Plant and Soil, 385, 87-105. https://doi.org/10.1007/s11104-014-2198-2

[67] Vochozka, M., Marouskova, A., Vachal, J. and Strakova, J. (2016) Biochar Pricing Hampers Biochar Farming. Clean Technologies Environmental Policy, 18, 1225-1231. https://doi.org/10.1007/s10098-016-1113-3

[68] Pirraglia, A., Gonzalez, P., Denig, J. and Saloni, D. (2013) Technical and Economic Modeling for the Production of Torrefied Lignocellulosic Biomass for the U.S. Densified Fuel Industry. BioEnergy Research, 6, 263-275. https://doi.org/10.1007/s12155-012-9255-6

[69] Rengsirikul, K., Ishii, Y., Kangvansaichol, K., Pripanapong, P., Sripichitt, P., Punsuvon, V., Vaithanomsat, P., Nakamanee, G. and Tudsri, S. (2011) Effects of Inter-Cutting Interval on Biomass Yield, Growth Components and Chemical Composition of Napiergrass (Pennisetum purpureum Schumach) Cultivars as Bioenergy Crops in Thailand. Grassland Science, 57, 135-141. https://doi.org/10.1111/j.1744-697X.2011.00220.x

[70] World Bank Group, Food and Agricultural Organization, Fertilizer Consumption (Kilograms per Hectare of Arable Land).

https://data.worldbank.org/indicator/AG.CON.FERT.ZS 
[71] Bargmann, I., Rillig, M.C., Kruse, A., Greef, J.-M. and Kücke, M. (2014) Effects of Hydrochar Application on the Dynamics of Soluble Nitrogen in Soils and on Plant Availability. Journal of Plant Nutrition and Soil Science, 177, 48-58. https://doi.org/10.1002/jpln.201300069

[72] Enders, A., Hanley, K., Whitman, T., Joseph, S. and Lehmann, J. (2012) Characterization of Biochars to Evaluate Recalcitrance and Agronomic Performance. Bioresource Technology, 114, 644-653.

https://doi.org/10.1016/j.biortech.2012.03.022

[73] Koide, R.T., Nguyen, B.T., Skinner, R.H., Dell, C.J., Peoples, M.S., Adler, P.R. and Drohan, P.J. (2015) Biochar Amendment of Soil Improves Resilience to Climate Change. GCB Bioenergy, 7, 1084-1091. https://doi.org/10.1111/gcbb.12191

[74] Mahadevan, R., Adhikari, S., Shakya, R., Wang, K., Dayton, D.C., Li, M., Pu, Y. and Ragauskas, A.J. (2016) Effect of Torrefaction Temperature on Lignin Macromolecule and Product Distribution from HZSM-5 Catalytic Pyrolysis. Journal of Analytical and Applied Pyrolysis, 122, 95-105. https://doi.org/10.1016/j.jaap.2016.10.011 